\title{
Improvement of physical and sensory properties of whipping cream by replacing sucrose with rebaudioside $A$, isomalt and maltodextrin
}

\author{
Mohamad Hossein AHOUEI ${ }^{1}$, Rezvan POURAHMAD ${ }^{1 \star}$, Ali Akbarian MOGHARI ${ }^{2}$
}

\begin{abstract}
The aim of this study was to produce sugar-free whipping cream with desirable quality. Rebaudioside A and isomalt were used as a sucrose substitute and maltodextrin to adjust the taste and texture of the whipping cream. Samples containing different amounts of rebaudioside A, isomalt and maltodextrin (50\% Rebaudioside A+50\%Isomalt, 50\% Rebaudioside A +50\%Maltodextrin, 50\% Rebaudioside A +25\%Isomalt+25\% Maltodextrin, 60\% Rebaudioside A +40\%Isomalt, 60\% Rebaudioside A +40\% Maltodextrin, $60 \%$ Rebaudioside A $+20 \%$ Isomalt+20\% Maltodextrin) were stored for two months. During storage, the syneresis of the samples decreased, but the viscosity increased significantly $(\mathrm{p} \leq 0.05)$. The lowest syneresis value was recorded for the sample containing $60 \%$ rebaudioside $\mathrm{A}+20 \%$ isomalt $+20 \%$ maltodextrin and this sample had the best texture. The sample containing $60 \%$ rebaudioside $\mathrm{A}+40 \%$ isomalt scored highest for flavor and overall acceptance. The sample containing $60 \%$ rebaudioside $\mathrm{A}+40 \%$ isomalt and the one containing $60 \%$ rebaudioside $\mathrm{A}+20 \%$ isomalt $+20 \%$ maltodextrin had the best sensory and physical qualities, respectively. Therefore, rebaudioside A, isomalt and maltodextrin can be used as a sucrose substitute to sweeten and provide suitable texture to whipping cream.
\end{abstract}

Keywords: isomalt; maltodextrin; rebaudioside A; whipping cream.

Practical Application: This study replaced sucrose with rebaudioside A, isomalt and maltodextrin in whipping cream to improve the physical and sensory qualities of the product. It was shown that functional sugar-free whipping cream could be produced. The use of these low-calorie sweeteners in whipping cream production is cost-effective and can be extended to industrial scale.

\section{Introduction}

Cream is milk fat that contains globules that are protected by a membrane. It is an oil-in-water emulsion with a complexity different from that of other emulsions because the surface of the fat globules is covered by a lipoprotein membrane (Noda \& Shiinoki, 1986; Wasan, 2000). It usually contains about $35 \%$ fat (Davidson, 2014). Nowadays, it is prepared by centrifugation followed by heat treatment to be used for food products such as coffee, tea, bread and cake (Matsumiya et al., 2017).

Whipping cream that contains high levels of fat (35\%-40\%) is distributed in sweetened or unsweetened form in markets (Rhothwell, 1983). Whipping cream is used in desserts, pastries, cakes, ice cream and some types of coffee (Camacho et al., 1998; Sajedi et al., 2014). This product is a complex emulsion-based foam structure in which partially coalesced fat droplets stabilize air bubbles at the air-water interface (Sajedi et al., 2014). Whipping cream contains high levels of fat and sucrose. Iranian National Standard 13653 permits manufacturers to add up to $25 \%$ sucrose to whipping cream (Institute of Standards and Industrial Research of Iran, 2013).

Sweeteners are used in many food products as sucrose substitutes and a variety of non-caloric sweeteners are in use. These sweeteners provide a high level of sweetness in low or very low amounts. It is similar to the sweetness of sucrose but is not absorbed by the body and does not the have the risks associated with sucrose, such as obesity, tooth decay and diabetes (O’Brien-Nabors, 2011).

Stevia rebaudiana is a variety of wild chrysanthemum (Smith, 1991) that originates in the Rio Monday valley of northern Paraguay. Stevia is natural strong and non-nutritive sweetener that is distributed in the form of a colorless, odorless, crystalline powder (Kroyer, 2010). It has a suitable taste that is similar to sucrose without an aftertaste, but is 250-300 times sweeter (Belitz et al., 2009). It is stable during processing and storage and, in solid form, at high temperatures (up to $120^{\circ} \mathrm{C}$ ) for one hour (Kroyer, 2010). Stevia has no effect on the blood sugar (Glucose) levels of humans with diabetes. It does not cause neurological complications or kidney disease. It has been shown to have anti-fungal and anti-bacterial effects (Goyal et al., 2010). There is no risk to teeth after consumption of stevia (Kinghorn, 2001). The results of animal studies have shown that stevia does not cause mutagenic damage or have genotoxic effects (O’Brien-Nabors, 2011).

Rebaudioside $\mathrm{A}$ is a glycoside from stevia with a diterpene structure. Its chemical formula is $\mathrm{C}_{44} \mathrm{H}_{70} \mathrm{O}_{23}$, its molecular 
weight is $967.013 \mathrm{~g} / \mathrm{mol}$ and its pure form is a white powder with a melting point of $242-244^{\circ} \mathrm{C}$ and an optical rotation is of $-33^{\circ}$. Rebaudioside A shows very good resistance to heat can withstand the pasteurization and sterilization temperatures of food products, particularly dairy products. In dairy products that are intended to be sweetened with sweetener, it is one of the best options (Mizutani, 2000).

Isomalt is a sweet, low-calorie bulking agent with properties and characteristics similar to sucrose. It is a sugar alcohol that is odorless, crystalline, and non-hygroscopic. It is a non-reducing sugar and optically active. Unlike sucrose, however, it is extremely stable with respect to chemical and enzymatic hydrolysis. It cannot be fermented by a large number of yeasts and other microorganisms found in nature. The sweetening power of isomalt lies between 0.45 and 0.60 as compared with that of sucrose (1.0). Isomalt has a pure sweet taste that is similar to sucrose without an aftertaste. Several sugar alcohols used as sugar substitutes have a high negative heat in solution. Although this mouth-cooling effect is a desirable feature for peppermint or menthol products, it is considered atypical in many other products. Only about $50 \%$ of isomalt converts into available energy; thus, it is suitable for controlling diabetes. As sugar alcohols have low digestibility, consumption of large amounts may result in a laxative effect. For certain applications, special types of isomalt have been developed. These include isomalt-ST, isomalt-HB, isomalt-GS, isomalt-DC and isomalt-LM. Isomalt-ST is the best type known. Extensive toxicological and metabolic studies have been conducted that prove conclusively the safety of isomalt (O’Brien-Nabors, 2011).

Maltodextrin is a modified starch derivative and non-sweet saccharide polymer with a dextrose equivalent (DE) of between 3 and 20. It has very little or no sweetness and is bland with no starchy flavor to mask other flavors. Maltodextrin is a fully-soluble carbohydrate of low bulk density. It can be metabolized in a way similar to starch and its application is suitable for diabetics. Two types of maltodextrin are in commercial use and have DEs of 10-14 and 15-19. The use of maltodextrin is widespread in the food industry because it can perform multifaceted functions in food systems. A wide range of such products is available in powder and syrup form. Its properties and the low cost of maltodextrin make it ideally suitable to be used in food. Maltodextrin has a suitably creamy feel and texture in the mouth and can hold water in foodstuffs very well. It is possible to reach the desired sweetness by using maltodextrin in combination one or more sweeteners or sugars (Kennedy et al., 1995). In creams with high levels of fat and in whipping cream, maltodextrin can be used to reduce the fat content. Moreover, maltodextrin causes gelation, water blocking and maintains the quality of whipping cream. It is an enhancing agent for dry matter and viscosity in cream with a high fat content and whipping cream (Sepenja et al., 2010).

Studies have investigated the use of some sweeteners as sugar substitutes in food products. Aidoo et al. (2015) investigated the effect of the use of stevia, tomatin, inulin and polydextrose on the characteristics of sugar-free chocolate. They reported that the rheological properties of sugar-free chocolates were similar to those of the control sample. Moreover, Ozdemir et al. (2015) investigated the use of stevia and cocoa powder in ice cream. They found that a sample containing stevia and cocoa powder had the highest viscosity and overrun. The purpose of the current study was to replace sucrose with rebaudioside $\mathrm{A}$, isomalt and maltodextrin in whipping cream and investigate its qualitative characteristics.

\section{Materials and methods}

\subsection{Materials}

This study used cream (42\% fat; Pegah; Iran), skimmed milk (0.15\% fat; Pegah; Iran), Rebaudioside A (Bene; Germany), isomalt (ST; Bene; Germany), maltodextrin ( $\mathrm{DE}=18$; FIG; China), commercial stabilizer for whipping cream (Danisco; Denmark) and sucrose (crystallized sugar; Livi; Iran).

\subsection{Producing whipping cream}

The fat content of the whipping cream samples first was adjusted to $35 \%$ by adding skimmed milk according to the Pearson square ration formulation. Next, the cream was poured into a stainless steel container, placed in a bain-marie and heated to a temperature of $50^{\circ} \mathrm{C}$. The commercial stabilizer was added first, then the rebaudioside $\mathrm{A}$, isomalt and maltodextrin in accordance with the relative sweetness of the sucrose. The control sample contained only sucrose (crystallized sugar; Livi; Iran). The samples were stirred by mixer in the stainless steel container (Sumber; Indonesia). The containers then were removed and cooled to $10^{\circ} \mathrm{C}$. Finally, $2 \mathrm{~kg}$ of each sample was poured into plastic containers having a capacity of $2.5 \mathrm{~kg}$ and stored at $5{ }^{\circ} \mathrm{C}$ for $24 \mathrm{~h}$. The treatments are shown in Table 1.

\subsection{Physicochemical analysis}

The dry matter was determined using a moisture analyzer (Sartorius; Germany) by carefully spreading $3 \mathrm{~g}$ of sample onto aluminum foil until it was covered and placing it in the moisture analyzer. After the water evaporated, the value was shown on the moisture analyzer (Nielsen, 2010).

Syneresis was measured by centrifuge (Sigma; Germany) at $1100 \mathrm{rpm}$ for $5 \mathrm{~min}$ at $25^{\circ} \mathrm{C}$ (Sajedi et al., 2014). Viscosity was measured using a Brookfield rotational viscometer (Brookfield; USA) using a spindle number of $4(\mathrm{LV}-4)$ with sear rate of $1 / \mathrm{sec}$ at $25^{\circ} \mathrm{C}$ (Nielsen, 2010).

\subsection{Sensory evaluation}

Eight trained panelists evaluated the sensory properties (flavor, texture and overall acceptability) according to a 9-point hedonic scale.

\subsection{Statistical analysis}

Testing was conducted using a completely randomized design. ANOVA and Duncan's multiple range test were used for analysis of data. Data analysis was carried out using SPSS 19 software. 
Table 1. The treatments of the study.

\begin{tabular}{|c|c|c|c|c|c|c|c|}
\hline No. & Sample & $\begin{array}{l}\text { Sucrose } \\
\text { (gram) }\end{array}$ & $\begin{array}{l}\text { Cream } \\
(\text { gram })\end{array}$ & $\begin{array}{c}2 \text { types of } \\
\text { Stabilizer } \\
(\mathrm{gram})\end{array}$ & $\begin{array}{c}\text { Rebaudioside } \\
\text { A (gram) }\end{array}$ & $\begin{array}{l}\text { Isomalt ST } \\
\text { (gram) }\end{array}$ & $\begin{array}{c}\text { Maltodextrin } \\
\text { with } \mathrm{DE}=18 \\
(\mathrm{gram})\end{array}$ \\
\hline 1 & Control & 500 & 1500 & $1.5+4.5$ & 0 & 0 & 0 \\
\hline 3 & 50\% Rebaudioside A $+50 \%$ Maltodextrin & 0 & 1500 & $1.5+4.5$ & 1 & 0 & 500 \\
\hline 4 & $50 \%$ Rebaudioside A $+25 \%$ Isomalt $+25 \%$ Maltodextrin & 0 & 1500 & $1.5+4.5$ & 1 & 250 & 250 \\
\hline 7 & $60 \%$ Rebaudioside A $+20 \%$ Isomalt $+20 \%$ Maltodextrin & 0 & 1500 & $1.5+4.5$ & 1.2 & 200 & 200 \\
\hline
\end{tabular}

ST: Standard Isomalt, DE: Dextrose Equivalent.

Table 2. The dry matter (\%) values of whipping cream samples during storage (mean \pm SD).

\begin{tabular}{|c|c|c|c|c|}
\hline No. & Sample & First day & $30^{\text {th }}$ day & $60^{\text {th }}$ day \\
\hline 1 & Control & $52.30 \pm 0.15^{\mathrm{abcA}}$ & $52.30 \pm 0.15^{\mathrm{abA}}$ & $52.30 \pm 0.20^{\mathrm{abcA}}$ \\
\hline 2 & 50\% Rebaudioside A +50\%Isomalt & $52.32 \pm 0.01^{\mathrm{aA}}$ & $52.33 \pm 1.15^{\mathrm{aA}}$ & $52.33 \pm 0.27^{\mathrm{aA}}$ \\
\hline 3 & $50 \%$ Rebaudioside A $+50 \%$ Maltodextrin & $52.30 \pm 0.01^{\mathrm{abcA}}$ & $52.29 \pm 1.15^{\mathrm{abcA}}$ & $52.30 \pm 1.11^{\mathrm{abcA}}$ \\
\hline 4 & $50 \%$ Rebaudioside A $+25 \%$ Isomalt $+25 \%$ Maltodextrin & $52.31 \pm 0.01^{\mathrm{abA}}$ & $52.30 \pm 1.15^{\mathrm{abA}}$ & $52.31 \pm 1.31^{\mathrm{abA}}$ \\
\hline 5 & $60 \%$ Rebaudioside A +40\%Isomalt & $49.68 \pm 0.08^{\text {defA }}$ & $49.68 \pm 0.01^{\mathrm{defA}}$ & $49.68 \pm 0.03^{\mathrm{deA}}$ \\
\hline 6 & $60 \%$ Rebaudioside A $+40 \%$ Maltodextrin & $49.69 \pm 0.07 \mathrm{deA}$ & $49.69 \pm 0.01^{\mathrm{deA}}$ & $49.70 \pm 0.06^{\mathrm{dA}}$ \\
\hline
\end{tabular}

The different small letters show the significant difference in each column ( $\mathrm{p} \leq 0.05)$; The different capital letters show the significant difference in each row ( $\mathrm{p} \leq 0.05)$.

\section{Results and discussion}

\subsection{Physicochemical characteristics}

Table 2 shows that significant differences $(\mathrm{p} \leq 0.05)$ were observed between the dry matter samples at 1,30 and 60 days after production. On all days, the highest percentages of dry matter were found in samples 1 (control), 2 (50\% rebaudioside $\mathrm{A}+50 \%$ isomalt), 3 (50\% rebaudioside $\mathrm{A}+50 \%$ maltodextrin) and 4 ( $50 \%$ rebaudioside $A+25 \%$ isomalt $+25 \%$ maltodextrin). The lowest percentages of dry matter were found in samples 5 (60\% rebaudioside $A+40 \%$ isomalt), 6 (60\% rebaudioside $A+40 \%$ maltodextrin) and 7 ( $60 \%$ rebaudioside $A+20 \%$ isomalt $+20 \%$ maltodextrin). Decreasing the isomalt and maltodextrin contents in other samples caused a significant difference $(p \leq 0.05)$ because the amount of cream in all samples was similar. The complete removal of sucrose from the product and its replacement with isomalt created an acceptable percentage of dry matter (O'Brien-Nabors, 2011). The addition of maltodextrin increased the dry matter of the product, which is consistent with the findings of Kennedy et al. (1995). The results were in accordance with Iranian National Standard No.13653 (Institute of Standards and Industrial Research of Iran, 2013).

Table 3 shows that significant differences $(\mathrm{p} \leq 0.05)$ were observed in the level of syneresis of the samples. During storage, syneresis decreased significantly ( $\mathrm{p} \leq 0.05)$. On all days, the highest level of syneresis was recorded for sample 2 (50\% rebaudioside A $+50 \%$ isomalt). On day 1 , the lowest level of syneresis was recorded for sample 1 (control). On days 30 and 60, sample 7 (60\% rebaudioside $\mathrm{A}+20 \%$ isomalt $+20 \%$ maltodextrin) had the lowest syneresis level. The syneresis of samples was found to be inversely proportional to the amount of maltodextrin. This agrees with the findings of Kennedy et al. (1995) and Sepenja et al. (2010). Syneresis indicates breakage of emulsion in whipping cream and is very closely related to viscosity. After stirring and transition of proteins in the serum phase, the viscosity increased, destroyed the elastic texture and created a viscose texture and syneresis decreased (Dinkson \& Starnsby, 1987).

Table 4 shows that, during storage, the viscosity of the samples increased significantly $(\mathrm{p} \leq 0.05)$. On day 1 , the highest viscosity was recorded for samples 3 (50\% rebaudioside $A+50 \%$ maltodextrin) and 6 (60\% rebaudioside $A+40 \%$ maltodextrin) and the lowest viscosity for samples 1 (control) and 5 (60\% rebaudioside $A+40 \%$ isomalt). On days 30 and 60 , sample 3 (50\% rebaudioside A $+50 \%$ maltodextrin) had the highest viscosity and the lowest viscosity was related to sample 7 (60\% rebaudioside $\mathrm{A}+20 \%$ isomalt $+20 \%$ maltodextrin) The viscosity was directly related to the amount of maltodextrin, which is in accordance with the findings of Kennedy et al. (1995) and Sepenja et al. (2010). Lindstam (1995) found that the optimum viscosity for whipping cream was $95-110 \mathrm{cP}$.

\subsection{Sensory characteristics}

Figure 1 indicates that significant differences $(\mathrm{p} \leq 0.05)$ were observed in the flavor scores of the samples. The highest flavor score was recorded for sample 5 ( $60 \%$ rebaudioside A $+40 \%$ isomalt) and the lowest for samples 3 ( $50 \%$ rebaudioside $A+50 \%$ maltodextrin) and 6 (60\% rebaudioside $A+40 \%$ maltodextrin). The samples containing isomalt and rebaudioside $\mathrm{A}$ received higher scores than those containing rebaudioside $\mathrm{A}+$ maltodextrin because 
Table 3. The amounts of syneresis (\%) of whipping cream samples during storage (mean \pm SD).

\begin{tabular}{cllll}
\hline No. & \multicolumn{1}{c}{ Sample } & First day & $30^{\mathrm{th}}$ day & $60^{\mathrm{th}}$ day \\
\hline $\mathbf{1}$ & Control & $1.79 \pm 0.02^{\mathrm{gA}}$ & $0.88 \pm 0.02^{\mathrm{fB}}$ & $0.40 \pm 0.01^{\mathrm{deC}}$ \\
$\mathbf{2}$ & $50 \%$ Rebaudioside A +50\%Isomalt & $2.81 \pm 0.05^{\mathrm{aA}}$ & $1.19 \pm 0.02^{\mathrm{aB}}$ & $0.57 \pm 0.02^{\mathrm{aC}}$ \\
$\mathbf{3}$ & $50 \%$ Rebaudioside A +50\%Maltodextrin & $2.24 \pm 0.02^{\mathrm{cA}}$ & $0.96 \pm 0.03^{\mathrm{cB}}$ & $0.43 \pm 0.03^{\mathrm{cC}}$ \\
$\mathbf{4}$ & $50 \%$ Rebaudioside A +25\%Isomalt+25\% Maltodextrin & $2.12 \pm 0.05^{\mathrm{eA}}$ & $0.93 \pm 0.02^{\mathrm{dB}}$ & $0.41 \pm 0.02^{\mathrm{dC}}$ \\
$\mathbf{5}$ & $60 \%$ Rebaudioside A +40\%Isomalt & $2.67 \pm 0.04^{\mathrm{bA}}$ & $1.10 \pm 0.02^{\mathrm{bB}}$ & $0.52 \pm 0.02^{\mathrm{bC}}$ \\
$\mathbf{6}$ & $60 \%$ Rebaudioside A +40\% Maltodextrin & $2.15 \pm 0.05^{\mathrm{dA}}$ & $0.90 \pm 0.01^{\mathrm{eB}}$ & $0.41 \pm 0.02^{\mathrm{dC}}$ \\
$\mathbf{7}$ & $60 \%$ Rebaudioside A +20\%Isomalt+20\% Maltodextrin & $2.02 \pm 0.08^{\mathrm{fA}}$ & $0.83 \pm 0.03^{\mathrm{gB}}$ & $0.38 \pm 0.02^{\mathrm{fC}}$ \\
\hline
\end{tabular}

The different small letters show the significant difference in each column ( $\mathrm{p} \leq 0.05)$; The different capital letters show the significant difference in each row ( $\mathrm{p} \leq 0.05)$.

Table 4. The viscosity (cp) values of whipping cream samples during storage (mean \pm SD).

\begin{tabular}{cllll}
\hline No. & \multicolumn{1}{c}{ Sample } & First day & $30^{\text {th }}$ day & $60^{\text {th }}$ day \\
\hline $\mathbf{1}$ & Control & $114.57 \pm 0.21^{\mathrm{eC}}$ & $198.44 \pm 1.71^{\mathrm{deB}}$ & $294.53 \pm 3.45^{\mathrm{dA}}$ \\
$\mathbf{2}$ & $50 \%$ Rebaudioside A +50\%Isomalt & $117.62 \pm 1.12^{\mathrm{dC}}$ & $203.23 \pm 1.91^{\mathrm{cB}}$ & $300.24 \pm 2.11^{\mathrm{cA}}$ \\
$\mathbf{3}$ & $50 \%$ Rebaudioside A +50\%Maltodextrin & $135.77 \pm 1.16^{\mathrm{aC}}$ & $218.59 \pm 1.51^{\mathrm{aB}}$ & $321.09 \pm 1.12^{\mathrm{aA}}$ \\
$\mathbf{4}$ & $50 \%$ Rebaudioside A +25\%Isomalt+25\% Maltodextrin & $126.29 \pm 1.85^{\mathrm{cC}}$ & $200.68 \pm 0.58^{\mathrm{dB}}$ & $300.28 \pm 1.93^{\mathrm{cA}}$ \\
$\mathbf{5}$ & $60 \%$ Rebaudioside A +40\%Isomalt & $113.94 \pm 0.92^{\mathrm{efC}}$ & $192.97 \pm 3.16^{\mathrm{fB}}$ & $292.67 \pm 1.91^{\mathrm{deA}}$ \\
$\mathbf{6}$ & $60 \%$ Rebaudioside A +40\% Maltodextrin & $133.15 \pm 0.12^{\mathrm{abC}}$ & $211.33 \pm 1.19^{\mathrm{bB}}$ & $309.79 \pm 1.79^{\mathrm{bA}}$ \\
$\mathbf{7}$ & $60 \%$ Rebaudioside A +20\%Isomalt $+20 \%$ Maltodextrin & $117.00 \pm 3.12^{\mathrm{cC}}$ & $183.80 \pm 1.53^{\mathrm{gB}}$ & $279.17 \pm 1.43^{\mathrm{fA}}$ \\
\hline
\end{tabular}

The different capital letters show the significant difference in each row $(\mathrm{p} \leq 0.05)$.

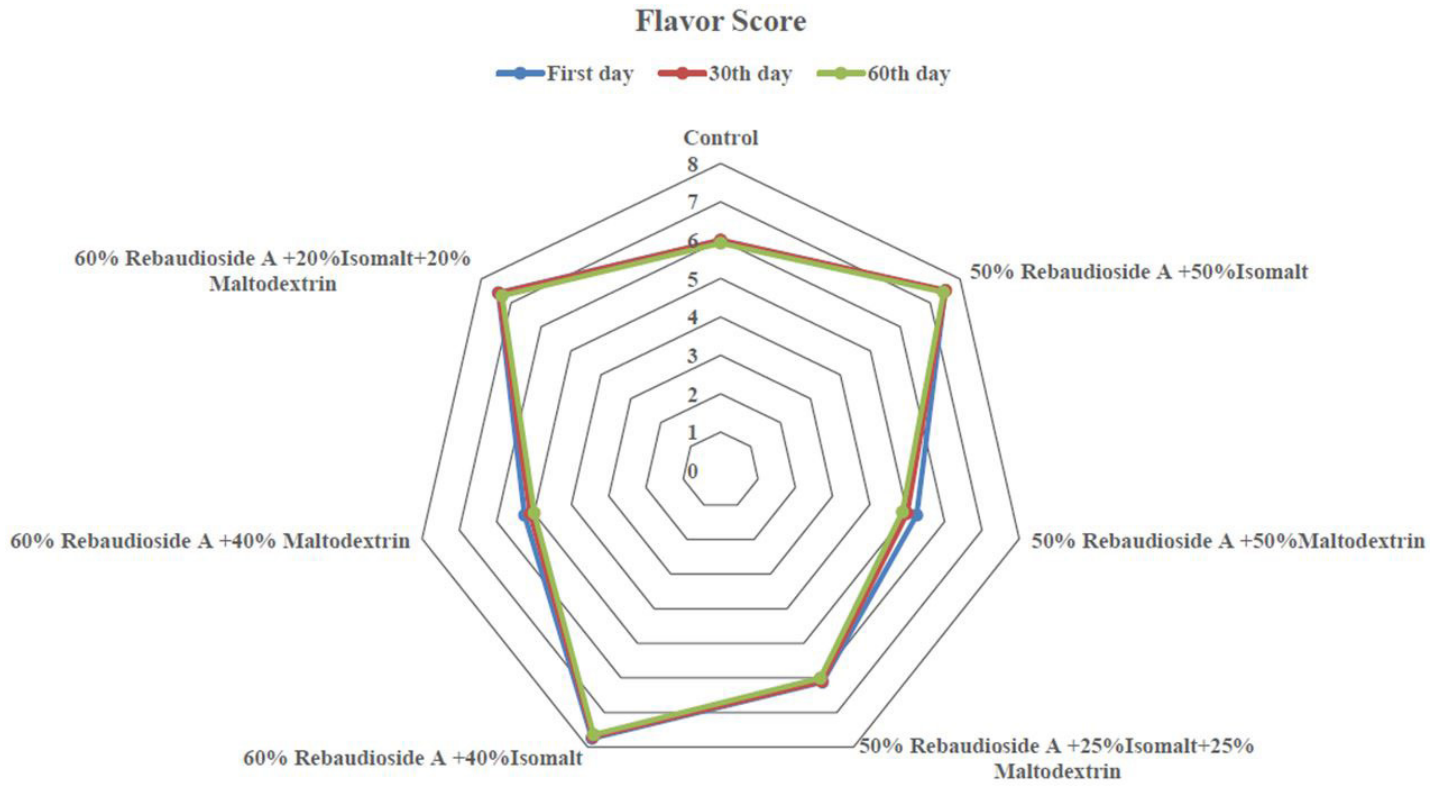

Figure 1. The flavor score of whipping cream samples during storage.

the decrease in sweetness of the product was masked by the maltodextrin. This agrees with the findings of Kennedy et al. (1995) and O’Brien-Nabors (2011).

Figure 2 shows that significant differences $(\mathrm{p} \leq 0.05)$ were observed in the texture scores of the samples. The highest texture score was recorded by sample 7 (60\% rebaudioside A $+20 \%$ isomalt $+20 \%$ maltodextrin) and the lowest by sample 1 (control). Samples containing isomalt or maltodextrin and those containing both were scored as more pleasing by the panelists than those after the removal of sucrose. These also exhibited a more pleasing texture in the mouth for sweetened whipping cream. The creation of a suitable texture with the use of isomalt is in accordance with the findings of O'Brien-Nabors (2011). The favorable of properties of maltodextrin were in accordance with the findings of Kennedy et al. (1995).

Figure 3 indicates that significant differences $(\mathrm{p} \leq 0.05)$ were observed in the overall acceptability score of the samples. The highest overall acceptability was recorded for sample 


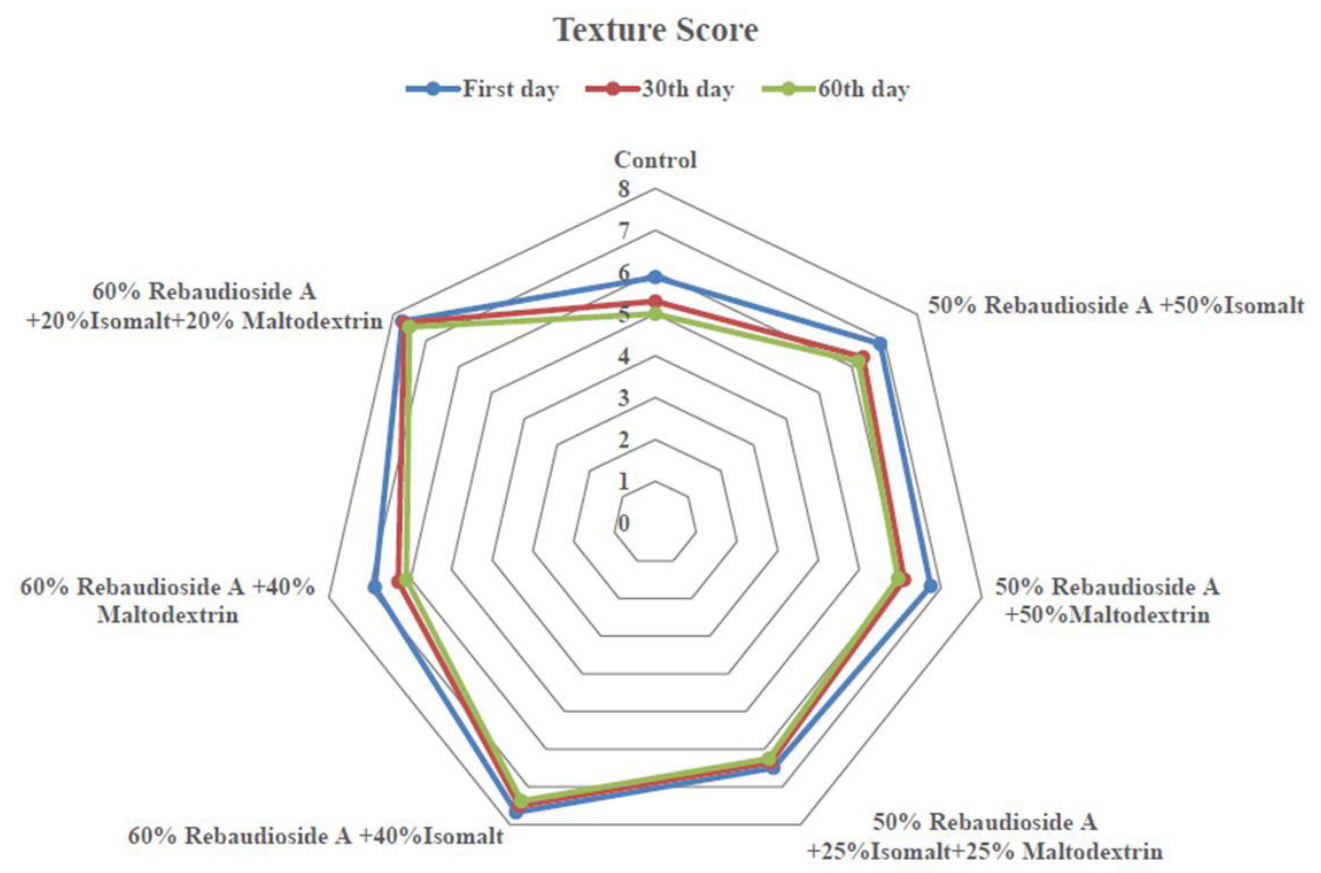

Figure 2. The texture score of whipping cream samples during storage.

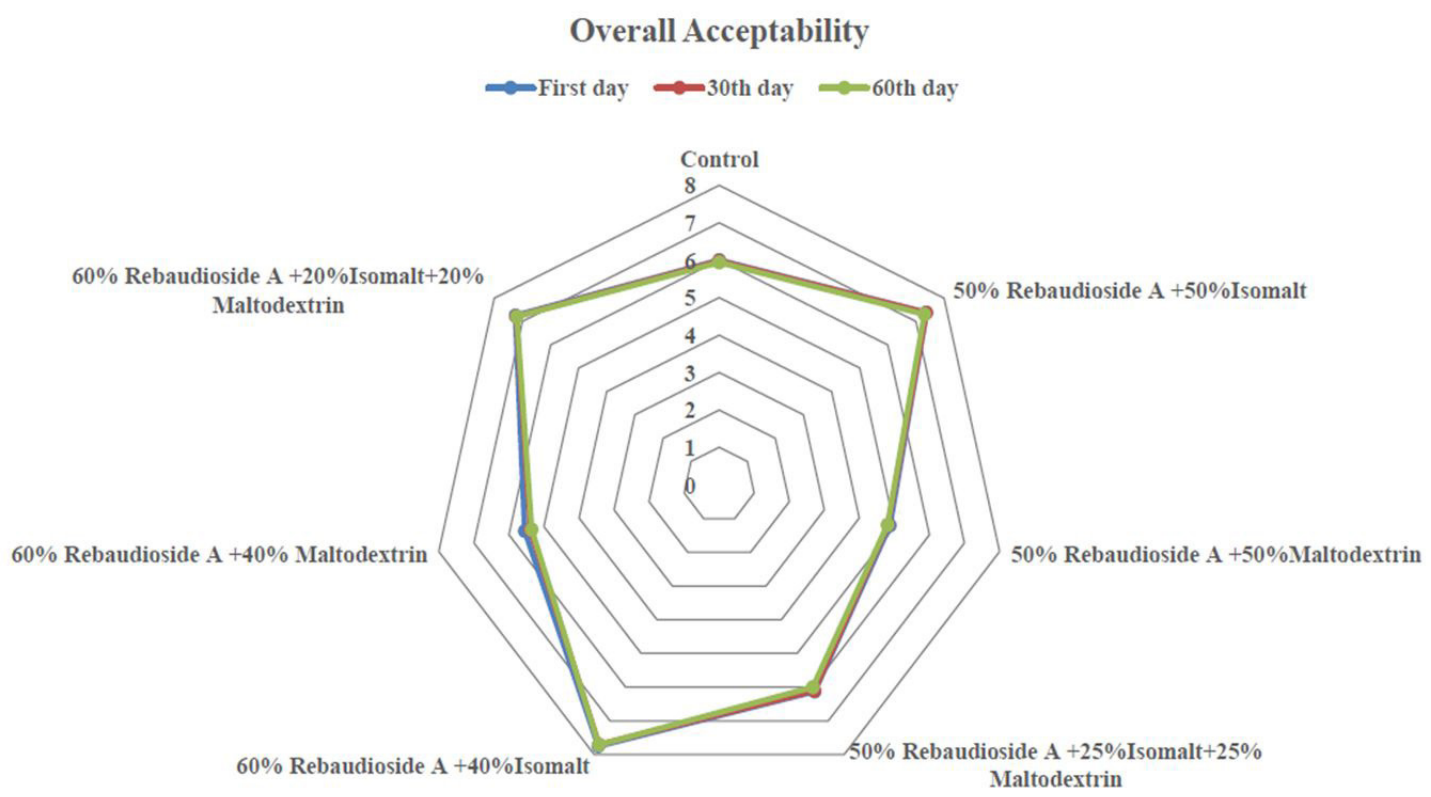

Figure 3. The overall acceptability score of whipping cream samples during storage.

5 (60\% rebaudioside $A+40 \%$ isomalt) and the lowest for sample 3 (50\% rebaudioside A $+50 \%$ maltodextrin). Samples containing rebaudioside $\mathrm{A}+$ isomalt and those containing rebaudioside $\mathrm{A}+$ isomalt + maltodextrin were more desirable than those containing rebaudioside $\mathrm{A}+$ maltodextrin and received higher scores. This agrees with the findings of O'Brien-Nabors (2011).

\section{Conclusion}

Replacing the sucrose in whipping cream with rebaudioside $\mathrm{A}$, isomalt and maltodextrin improved its physical and sensory properties. The addition of maltodextrin increased the viscosity and decreased syneresis, which improved the texture, an important factor for both industry and the consumer. The use of rebaudioside A and isomalt gave the product a sweet taste similar to that of 
sucrose, or even better. During replacement of sucrose with rebaudioside $\mathrm{A}$, isomalt and maltodextrin, special attention should be paid to the balance of sweeteners and maltodextrin to assure that the characteristics of the product approximate the amount of sucrose and its sweetness. The small amounts of rebaudioside A needed and nominal price of isomalt and maltodextrin make their use in whipping cream cost efficient. This product is healthy and safe.

\section{References}

Aidoo, R. P., Afoakwa, E. O., \& Dewettinck, K. (2015). Rheological properties, melting behaviours and physical quality characteristics of sugar-free chocolates processed using inulin/polydextrose bulking mixtures sweetened with stevia and thaumatin extracts. Lebensmittel-Wissenschaft + Technologie, 62(1), 592-597. http:// dx.doi.org/10.1016/j.lwt.2014.08.043.

Belitz, H. D., Grosch, W., \& Schieberle, P. (2009). Food chemistry (1114 p.). Berlin: Walter de Gruyter.

Camacho, M. M., Martínez-Navarrete, N., \& Chiralt, A. (1998). Influence of locust been gum and carrageenan mixtures on whipping and mechanical properties and stability of dairy cream. Food Research International, 31(9), 653-658. http://dx.doi.org/10.1016/S09639969(99)00041-1.

Davidson, A. (2014). Dairy products. In T. Jaine (Ed.), The oxford companion to food. Oxford: Oxford University Press. http://dx.doi. org/10.1093/acref/9780199677337.001.0001.

Dinkson, E., \& Starnsby, G. (1987). Progress in the formulation of food emulsion and foams. Food Technology, 41(9), 74-82.

Goyal, S. K., Samsher, M., \& Goyal, R. K. (2010). Stevia (Stevia rebaudiana) a bio-sweetener: a review. International Journal of Food Sciences and Nutrition, 61(1), 3-10. http://dx.doi.org/10.3109/09637480903193049. PMid:19961353.

Institute of Standards and Industrial Research of Iran. (2013). Flavored pasteurization and ultra high temperature (UHT) cream and characteristics: Iranian National Standard (No. 13653). Tehran: ISIRI.

Kennedy, J. F., Knill, C. J., \& Taylor, D. W. (1995). Starch hydrolysis products and their derivatives (pp. 65-82). United Kingdom: Chapman and Hall. http://dx.doi.org/10.1007/978-1-4615-2159-4_3.
Kinghorn, A. D. (2001). The genus stevia (89 p.). USA: Department of Medicinal Chemistry and Pharmacognosy University of Illinois in Chicago.

Kroyer, G. (2010). Stevioside and Stevia- sweetener in food: application, stability and I nteraction with food ingredients. Journal für Verbraucherschutz und Lebensmittelsicherheit, 5(2), 225-229. http:// dx.doi.org/10.1007/s00003-010-0557-3.

Lindstam, N. C. (1995). Process for production of beatable cream of low fat content (pp. 21-27). London: Chemical Publishing Co.

Matsumiya, K., Horiguchi, S., Kosugi, T., Mutoh, T., Nambu, Y., Nishimura, K., \& Matsumura, Y. (2017). Effects of heat treatment and homogenization on milk fat globules 19 and proteins in whipping creams. Food Structure, 12, 94-102. http://dx.doi.org/10.1016/j. foostr.2017.02.003.

Mizutani, K. (2000). Pharmaceuti maruzen sweets (226 p.). Hiroshima: Fukuyama.

Nielsen, S. S. (2010). Food analysis (215 p.). USA: Purdue University west Lafayeee.

Noda, M., \& Shiinoki, Y. (1986). Microstructure and rheological behavior of whipping cream. Journal of Texture Studies, 17(2), 189-204. http:// dx.doi.org/10.1111/j.1745-4603.1986.tb00404.x.

O’Brien-Nabors, L. (2011). Alternative Sweeteners (587 p.). New York: Marcel Dekker. http://dx.doi.org/10.1201/b11242.

Ozdemir, C., Arslaner, A., Ozdemir, S., \& Allahyari, M. (2015). The production of ice cream using stevia as a sweetener. Journal of Food Science and Technology, 2(7), 1200-1214.

Rhothwell, J. (1983). Cream processing manual (pp. 14-17). Huntingdon: Society of Dairy Technology.

Sajedi, M., Nasirpour, A., Keramat, J., \& Desobry, S. (2014). Effect of modified whey protein concentrate on physical properties and stability of whipped cream. Food Hydrocolloids, 36, 93-101. http:// dx.doi.org/10.1016/j.foodhyd.2013.09.007.

Sepenja, K., Hyma, O., Parkliva, T., \& Leili, P. (2010). Chantilli cream and ice cream without fat. Journal of Food Technology, 12(2), 182-189.

Smith, J. (1991). Food additive. London: Blackie and Son.

Wasan, D. T. (2000). Emulsions, foams and thin films (pp. 1181-1192). New York: Marcel Dekker. 